\title{
Viewpoint:
}

\section{Revegetating the West: Where is it Going?}

\author{
A discussion on the effectiveness and economics \\ of local ecotype plants vs. native plants for restoration.
}

\author{
By Don Hijar
}

A s a seedsman who has been involved with conservation through the Soil Conservation

Service and private industry, I have worked with countless farmers/ranchers, government agencies, and other organizations trying to protect the most fundamental of resources: soil.

After all these years I still believe that there is no better way to do this than with grass - the "miracle species." Grass works better than trees, shrubs or forbs in holding the soil in place. The issue at hand is what grass do we use where?

For some people this is a very black and white issue; restoration of ecosystems using plants that are "native," or even more specifically "local ecotype" should be the only option and if that can't be done, it shouldn't be seeded at all. The confusion comes in not only defining native and local ecotype, but also in agreeing on a common philosophy -and ultimately, Is anyone willing to pay for it?

\section{History Revisited}

First, I believe we need to have a historical perspective on how soil stabilization has been approached over the past $70-80$ years. During the Dustbowl years, the main concern was to provide permanent ground cover quickly. At that time our knowledge on establishing native grasses was very limited. We didn't know much about how and when to harvest, or how to condition the seed. Traditional farming equipment was not suited to drill the fluffy native seed, and so it was then broadcast seeded, which was often a failure.

Because we were so bad at harvesting native seed, we started to bring in easier to establish introduced grasses that tended to be bigger, heavier, smoother seed that was most similar to grain and easier to handle through traditional equipment. This method met the goal at that time, revegetation.

In the late 1970's as a result of the Mine Land Reclamation Act, reclamation of all types of mine sites became a priority. This was a very expensive proposition, but people were concerned about how these sites might affect the environment and cause health hazards through wind and water erosion. This resulted in requiring mining companies to submit a reclamation plan before any mining could be started. The science of reclamation was young and inexperienced and because starting grass on steep slopes with little or no topsoil is so challenging, the cheapest, easiest to establish, and most available seed was often chosen, generally introduced species.

This process has evolved so that now before a mine project is begun an Environmental Impact Statement is done including studies of what species are currently there so that they can try to duplicate the same species and density. Other approaches such as stockpiling topsoil and bare rootstock transplanting have contributed to reclamation success.

\section{Recent Issues}

When President Clinton signed the Invasive Species Executive Order in 1999 many took the concept of restoration and made the assumption that it meant using local ecotype. From a puritanical standpoint the idea is great, but from a practical and economic standpoint it is not very realistic.

There are many reasons why local ecotype seed is so expensive. It is a very labor intensive, high risk venture. Many plants are generally in smaller stands 
and need to be hand harvested, often the seed is hard or dormant, has poor seed heads and other germination and purity problems, and is difficult to clean. Some seed may take 30 days to three years to break dormancy and then produce low yields. It is basically a simple issue of supply and demand creating the high cost.

In 2001 I attended a tour of Rocky Mountain National Park and made the following observation of cost comparisons using different seed sources in that setting.

Rocky Mountain National Park has a nursery to propagate native local ecotype plants. The park has worked with the Natural Resource Conservation Service and the Upper Colorado Plant Material Center to increase the production of these local ecotypes. Restoration in the park uses local ecotype containerized plants wherever possible. I do not know the exact cost to restore one acre using all containerized plants, but it would be expensive. It would be less expensive if the park would use seed of this plant material rather than actual plants and it would be even less expensive if the park would use native species seed but not necessarily local ecotype. Less expensive, yet, would be using adaptable introduced species. The following is a cost comparison:

Introduced Mix - $50 \mathrm{lbs} / \mathrm{Ac}$ x $\$ 2 / \mathrm{lb}=\$ 100 / \mathrm{Ac}$ Native Seed Mix - $50 \mathrm{lbs} / \mathrm{Ac}$ x $\$ 10 / \mathrm{lb}=\$ 500 / \mathrm{Ac}$ Local Ecotype Seed Mix - 50 lbs/Ac x $\$ 100 / \mathrm{lb}=$ $\$ 5,000 / \mathrm{Ac}$

Containerized plants -1 plant $/ \mathrm{ft} ?=43,560$ plants $\mathrm{x} \$ 1 /$ plant $=\$ 43,560 / \mathrm{Ac}$

There sometimes are good reasons to use native local ecotype plant materials. I believe anywhere we can maintain the genetic integrity of an ecosystem, and can afford it, we should. However, as you can see the cost of restoring an ecosystem to its original state using native local ecotypes can be cost prohibitive. Due to the fact that there is no way to verify whether a plant or seed is from a particular ecotype other that physical verification at the time of harvest, there is tremendous potential for abuse and misrepresentation. How do we know we are getting what we pay for?

When you're talking about millions of acres in the Great Basin, will the taxpayers be willing to pay for local ecotype restoration? Beyond what it would cost in dollars, can we afford the time it would take to restore one acre at a time when millions of acres are at stake? In the time it would take to educate, raise funds, and do the restoration, noxious weeds will have an even more aggressive hold on our lands than they already do.

There is no easy answer how to approach the local ecotype issue as there are many influencing factors. Many of us have the same goals, just different methods of attaining them. Ultimately, what I would like to see is for the organizations working towards protecting our environment to have a meeting of the minds to find commonalities in resource protection rather than just furthering their own missions.

About the Author: Don Hijar is with Pawnee Buttes Seed, Inc. based in Greeley, Colo.. He grew up on an irrigated farm in the Arkansas Valley and graduated from Colorado State University with a B.S. in Animal Science. He worked with the Soil Conservation Service for seven years and has been in the seed industry for 19 years. Don is a PastPresident of the Colorado Seed Industry Association, PastPresident of the Colorado Section of the Society for Range Management, and Past-President of the Northern Chapter Associated Landscape Contractors of Colorado. He has served on numerous committees to further the cause of environmental stewardship. 